\title{
RESISTANCE TO PANCURONIUM IN AN ASTHMATIC PATIENT TREATED WITH AMINOPHYLLINE AND STEROIDS
}

\author{
Isaac Azar, Darshin Kumar and Albert M. Betcher
}

\begin{abstract}
A 17 year old male with a history of bronchial asthma was admitted to the intensive care unit in severe respiratory distress. During a two week period of intensive respiratory care he received large doses of aminophylline and corticosteroids. In addition, pancuronium was given to facilitate ventilation and to reduce airway pressure. Large doses of pancuronium, as much as $5 \mathrm{mg} / \mathrm{hr}$, were required to stop spontaneous respiratory efforts and restlessness. The total pancuronium dose given during the two week period was $800 \mathrm{mg}$. One hour after pancuronium was discontinued the patient could open his eyes and move his lips. Peripheral nerve stimulation indicated partial paralysis which improved promptly following a test dose of edrophonium.

The authors speculate that aminophylline, which is a known inhibitor of the enzyme phosphodiesterase, raised the level of c-AMP and, in turn, the level of acetylcholine at the neuromuscular junction and thus antagonized the blocking effect of pancuronium. In addition, the large doses of corticosteroids that the patient had received may have enhanced the release of acetylcholine and further facilitated neuromuscular transmission.
\end{abstract}

KEY WORDS: DRUG INTERACTION, pancuronium, aminophylline, steroids.

AMINOPHYLLINE ${ }^{1}$ and hydrocortisone ${ }^{2}$ have been shown to reverse the neuromuscular blocking effect of pancuronium. The following is a case report of resistance to pancuronium in an asthmatic patient receiving large doses of aminophylline and steroids.

\section{CASE REPORT}

The patient, a 17 years old male weighing $55 \mathrm{~kg}$, had a history of bronchial asthma and multiple hospitalizations due to repeated episodes of severe wheezing and respiratory distress from the age of three years. He had been taking aminophylline and terbutaline orally and inhaling nebulized metaproteranol and belcomethasone intermittently. On arrival in the emergency room on this admission the patient was in severe respiratory distress, unresponsive, and deeply cyanotic. Respiratory rate was $38 / \mathrm{min}$, blood pressure $21.3 / 10.6 \mathrm{kPa}$ (160/80 torr), and pulse $156 / \mathrm{min}$ and regular. The trachea was immedi-

Isaac Azar, M.D., Associate Professor and Associate Director; Darshin Kumar, M.D., Resident; Albert M. Betcher, M.D., Professor; Department of Anesthesiology, Beth Israel Medical Center and Mount Sinai School of Medicine (CUNY).

Address for reprints: Isaac Azar, M.D. 10 Nathan D. Perlman Place, New York, N.Y. 10003.

Can. Anaesth. Soc. J., vol. 29, no. 3, May 1982 ately intubated and the lungs ventilated mechanically, $10 \mathrm{ml} \cdot \mathrm{kg}^{-1}$ at a rate of 10 breaths $/ \mathrm{min}$, and the following medications were given: terbutaline $0.5 \mathrm{mg}$ subcutaneously, isoetharine $2.5 \mathrm{ml}$ by a nebulizer, hydrocortisone $250 \mathrm{mg}$ and aminophylline $500 \mathrm{mg}$ both intravenously. Diazepam $40 \mathrm{mg}$ and morphine $20 \mathrm{mg}$, in intermittent doses, were also given for sedation.

At first the patient's condition improved and his arterial blood gases on $\mathrm{FI}_{\mathrm{O}_{2}} 0.5$ were: $\mathrm{PO}_{2}$ $9.57 \mathrm{kPa}$ (72 torr), $\mathrm{PCO}_{2} 5.32 \mathrm{kPa}$ (40 torr), $\left[\mathrm{H}^{+}\right]$ a $46.77 \mathrm{nmol} / 1(\mathrm{pH} \mathrm{7.33)}$. But shortly thereafter his condition deteriorated: wheezing and airway pressure increased and arterial blood gases declined $\left(\mathrm{PO}_{2} 5.85 \mathrm{kPa}\right.$ (44 torr), $\mathrm{PCO}_{2} 7.98 \mathrm{kPa}$ (60 torr), $\left[\mathrm{H}^{+}\right]$a $125.89 \mathrm{nmol} / 1(\mathrm{pH} \mathrm{6.9})$ ) and the patient became combative. A variety of bronchodilators, steroids, sedatives, and pancuronium in large doses were given during the following two weeks (see Table I). Blood aminophylline level was maintained at 15$22 \mathrm{mg} / \mathrm{ml}$. Pancuronium was given whenever spontaneous respiratory efforts and restlessness increased airway pressure. However, single doses of pancuronium $2 \mathrm{mg}$, freshly obtained from the operating room daily, often failed to stop spontaneous respiratory efforts and a continuous infusion of $5 \mathrm{mg} / \mathrm{hr}$ was required. Several attempts to wean the patient off the ventilator 
TABLE I

The Following Drugs and Doses Were administered During a Two Week Period of Intensive Respiratory Therapy in an Asthmatic Patient

\begin{tabular}{llccc}
\hline \hline \multicolumn{1}{c}{ Drug } & \multicolumn{1}{c}{ Dose } & Route & Frequency & Total \\
\hline Terbutaline & $0.5 \mathrm{mg}$ & sc & q4h & $40 \mathrm{mg}$ \\
Aminophylline & $500 \mathrm{mg}$ bolust & iv & PRN & $7.2 \mathrm{gm}$ \\
& $1.3 \mathrm{mg} \cdot \mathrm{kg}^{-1} / \mathrm{hr}$ & & & \\
Isoctharine & $2.5 \mathrm{ml}$ & nebulized & PRN & $?$ \\
Hydrocortisone & $250 \mathrm{mg}$ & iv & q6h & $17 \mathrm{gm}$ \\
Prednisolone & $15 \mathrm{mg}$ & iv & daily & $195 \mathrm{mg}$ \\
Pancuronium & $2 \mathrm{mg}$ bolus & iv & PRN & $800 \mathrm{mg}$ \\
& and/or $5 \mathrm{mg} / \mathrm{hr}$ & & & \\
\hline
\end{tabular}

failed due to poor blood gases and excessive airway pressure. On the third day a tracheostomy was done.

After two weeks of intensive respiratory care the patient started to show signs of improvement: the wheezing diminished, chest $x$-ray cleared, and the arterial blood gases on $\mathrm{F}_{\mathrm{O}_{2}}, 0.3$ were: $\mathrm{Po}_{2}$ $13.03 \mathrm{kPa}$ (98 torr), $\mathrm{PCO}_{2} 3.99 \mathrm{kPa}$ (30 torr), and $\left[\mathrm{H}^{+}\right]$a $31.62 \mathrm{nmol} / 1(\mathrm{pH} 7.50)$. Liver and renal function remained within normal range during his hospital stay.

On the 14th day pancuronium was discontinued. One hour later the patient could open his eyes and move his lips. However, he made no spontaneous respiratory efforts and his extremities remained limp. Electrodiagnostic studies of the neuromuscular junction indicated residual non-depolarizing blockade. A test dose of intravenous edrophonium $10 \mathrm{mg}$ was followed by a dramatic improvement in muscular power. Urine, collected 24 hours after pancuronium administration had been discontinued, was analyzed and found to contain insignificant amounts of pancuronium.

The patient was gradually weaned off the ventilator and was discharged two weeks later in satisfactory condition. There was no evidence of neuromuscular compromise during that period of time.

\section{Discussion}

Pancuronium is excreted primarily by the kidneys and to a lesser degree by the liver. ${ }^{1}$ Twenty to fifty per cent of a single dose is excreted within 24 hours, most of it during the first 3-4 hours.' Other factors, such as drugreceptor dissociation rate and muscle perfusion, also determine the rate of recovery of the neuromuscular junction. ${ }^{2}$ We have no reason to believe that any of these factors operated abnormally in our patient, except for the possible effect of the beta adrenergic agents, terbutaline and isoetharine, on muscle perfusion. Beta adrenergic agents are known for their potent dilatory effect on arterioles of skeletal muscles ${ }^{3}$ and they could possibly facilitated the recovery of our patient from pancuronium.

In addition to the large doses of pancuronium, our patient also received large doses of aminophylline and corticosteroids, which are known for their interaction with muscle relaxants. Aminophylline antagonizes non-depolarizing muscle relaxants in the cat ${ }^{4}$ and in man. ${ }^{5}$ It is speculated that the mechanism of the aminophylline-induced resistance to muscle relaxants is based on the ability of aminophylline to inhibit the enzyme phosphodiesterase at the pre-junctional membrane of the neuromuscular junction, as do all theophyllines, and thus it increases c-AMP level. The high c-AMP level promotes acetylcholine release, which in turn antagonizes the blocking effect of non-depolarizing muscle relaxants.

Corticosteroids also have been shown to facilitate neuromuscular transmission. Hydrocortisone has been reported to reverse pancuronium-induced paralysis in an hypophysectomized patient. ${ }^{7}$ Although the mechanism is not completely clear, corticosteroids antagonize the blocking effect of hemicholinium-3 at the neuromuscular junction, possibly by facilitating choline transport at the pre-junctional membrane. ${ }^{8}$ This could also possibly be the mechanism of corticoid-induced reversal of pancuronium.

In summary, we feel that this patient exhibited resistance to pancuronium due to the antagonizing effect of aminophylline, and perhaps also of corticosteroids. Monitoring the neuromuscular junction with a nerve stimulator and titrating the dose of the muscle relaxant accordingly would improve the management of asthmtic patients in acute respiratory failure. 


\section{REFERENCES}

1. Agoston, S., Vermeer, G.A., Kersten, U.W., et al. The fate of pancuronium bromide in man. Acta Anaesthesiol. Scan. 17: 267-275 (1973).

2. STANSKI, D.R. \& Sheiner, L.B. Pharmacokinetics and dynamics of muscle relaxants (editorial). Anesthesiology 51: 103-105 (1979).

3. Goodman, L.S. \& Gilman, A. The Pharmacological Basis of Therapeutics, 5 th ed. Macmillan Publishing Co. p. 485 (1975).

4. Dretchen, K.L., Morgenroth, V.H. III, Standaert, F.G., et al. Azathioprine: effects on neuromuscular transmission. Anesthesiology 45: 604-609 (1976).
5. Doll, D.C. \& RosenberG, H. Antagonism of neuromuscular blockage by theophylline. Anesth. Analg. 58: 139-140 (1979)

6. Dretchen, K.L., Standaert, F.G., MorgenROTH, V.H. III, et al. . Evidence of prejunctional role of cyclic nucleotides in neuromuscular transmission. Nature 264: 79-81 (1976).

7. MEYER, E.F. Partial recovery from pancuronium neuromuscular blockade following hydrocortisone administration. Anesthesiology 1977; 46: $148-150(1977)$

8. LEEUWIN, R.S. \& WOLTER, E.J. Effect of corticosteroids on sciatic nerve-tibialis anterior muscle of rats treated with hemicholinium-3. Neurology 27: 171-177 (1977).

\section{RESUME}

On rapporte le cas d'un jeune homme de dix sept ans, présentant une histoire d'asthme bronchique, admis en détresse respiratoire à l'unité des soins intensifs. Au cours de son séjour de deux semaines dans cette unité, il reçut de fortes doses d'aminophylline et de corticoïdes. On lui administra également du pancuronium dans le but de faciliter la ventilation et de diminuer la pression intra-pulmonaire. Des doses importantes de cet agent, allant jusqu'à $5 \mathrm{mg} /$ heure, étaient nécessaires pour inhiber la respiration spontanée et l'agitation du malade: le patient a reçu $800 \mathrm{mg}$ de pancuronium au cours des deux semaines de son séjour aux soins intensifs. Une heure après l'administration du pancuronium, il pouvait ouvrir les yeux et bouger les lèvers. L'électro-stimulation indiquant une paralysie résiduelle qui s'améliorait rapidement après une dose test d'edrophonium.

Les auteurs croient que l'aminophylline, un inhibiteur de la phosphodiestérase, élevait le niveau de l'AMP cyclique et, conséquemment, celui de l'acétylcholine à la jonction myoneurale renversant ainsi le bloc du pancuronium. De plus, les fortes doses de corticoïdes administrées peuvent augmenter la libération d'acétylcholine, facilitant la transmission neuromusculaire. 